\title{
Political and Civil Society in India's Welfare Trajectory
}

\author{
Ellen Ehmke*
}

\begin{abstract}
In this article, a historical institutional approach is applied to study the Indian welfare trajectory. The aim is to understand which reproduction pattern possibly inhibited the constitutional call for adequate standards of living and welfare for India's citizens. Partha Chatterjee's concept of political and civil society forms a plausible reproduction mechanism, which offers a new explanation for the development of highly fragmented social policies. As a consequence of this mechanism, existing inequalities were perpetuated rather than overcome. However, the recent shift to rights-based social protection may challenge this pattern and allow for greater social policy change in the future.
\end{abstract}

\section{Introduction}

Social protection schemes are embedded in the wider socioeconomic context of welfare regimes. This has been a key insight from the welfare state debate in Organisation for Economic Cooperation and Development (OECD) countries. In non-OECD countries, where the state plays a smaller role in the provision of welfare, we might talk about 'welfare regimes' rather than 'welfare state regimes' (Gough 2004). ${ }^{1}$ Building on this analysis, this article introduces the concepts of 'welfare trajectories' to capture the historicity of welfare development, and 'reproduction patterns' to explain institutional stability or change in welfare arrangements.

After introducing our analytical framework, this article presents an analysis of institutional legacies of the Indian welfare regime. Since independence, the Republic of India has aspired to achieve welfare and greater equality for its citizens, yet its welfare trajectory has been torn between these universal ideals and fragmented political and social realities. This article identifies the mechanisms which obstructed the constitutional commitment to greater welfare for all citizens, and suggests that, after independence, existing inequalities were not successfully tackled. The failure to achieve egalitarian citizenship created a reproduction pattern which worked against the development of comprehensive social welfare provision. Instead, the politics of 'political society' (Chatterjee 2004) helped perpetuate inequalities and introduced hundreds of social welfare-related programmes which produced selective and temporary gains only for specific groups. Nevertheless, the recent swing towards social rights-based legislation might constitute a shift that shakes this pattern of reproduction and allows for greater institutional change in the future.

\section{$\mathbf{2}$ The analytical framework: welfare trajectories}

The concept of welfare trajectories draws on two important sources: the debate on welfare regimes in the South (Gough 2004; Rudra 2007; Haggard and Kaufman 2008), and historical institutional analysis (Thelen 1999). The former explores the systematic differences between welfare regimes in countries outside the OECD. The origins of such regimes and social policy development, according to Gough (2008: 58), can be analysed using the framework of the 'five Is': Industrialisation, Interests, Institutions, Ideas and International supra-state influences. Gough (2008: 63) stresses that social policy developments are embedded in economic and social structures and have to be analysed in their specific context. Rudra (2007: 391) highlights that 'the initial choice of development strategy and complementary welfare policies create distributional coalitions, which thereafter have a vested interest in maintaining existing institutions and reinforcing them'. Haggard and 
Kaufman (2008: 15) add that 'the effects of institutions are conditional on the distribution of underlying preferences over the policy in question and the strength of the contending social groups in the political process'. They conclude that the legacy of early social policies weighs heavily and limits the room for manoeuvre of today's actors in the field.

To understand institutional stability and change of today's welfare regimes, this article conceptualises them as welfare trajectories, which can be analysed using the approach of historical institutionalism. The approach includes two related, but analytically distinct, claims (Thelen 1999). First, the initial choice of policies in founding moments of institutional formation shape distinct development paths - the critical junctures. Second, institutional stability and change are constrained by past trajectories through patterns of reproduction, which have two components: incentive structures that guide individual and collective practices to sustain institutions or regulatory regimes, and distributional effects of institutions that reproduce and magnify the political distribution of power. Depending on the set of mechanisms on which an institution rests, it may be more or less prone to change. Understanding fundamental institutional change therefore requires an insight into the previous reproduction patterns which upheld earlier regulatory regimes.

\section{The formation of India's nascent welfare regime}

The formulation of India's Constitution and the social and economic planning in the first years of the republic were critical junctures for the institutionalisation of India's welfare trajectory, because self-governance was seen as more than a moral right: 'political freedom must include real economic freedom of the starving masses' (Congress 1931, cited in Kumar 2005: 338), according to the Indian National Congress. Hence, significant expectations were attached to the Constitution and the new republic. It took the over 300 members of the Constituents Assembly over three years to mould competing ideas on the role of the state, democracy, economy, religion, language and welfare into the Constitution's unified format (Guha 2007: 103-23). The first Prime Minister, Jawaharlal Nehru, and the Planning Commissions then shaped economic and social policies in a way which set the course of the welfare trajectory.
To understand the formation of the early social policy regime, we turn to the social question and the way it was initially framed in these two crucial phases, when two issues dominated the discussion: whether welfare should be groupbased and group-specific or universalist, and whether a more interventionist social policy agenda should be favoured over welfare development driven by economic modernisation.

\subsection{Group-based versus universal welfare provision}

Concerning welfare, as in other policy areas, traditions and hereditary ideologies rival modernising ideals. In pre-colonial and colonial times, the organisation of social welfare in India was fragmented, often charity- and group-based; for the Hindus within castes, for other religious communities mainly within a more broadly defined group of members (Muzumdar 1964). While the Muslim tradition of zakat entails mechanisms of redistribution in favour of the disadvantaged; the rigid hierarchical social order between castes involves extreme forms of social exclusion (Jürgenmeyer and Rösel 2009).

After long discussions, the constitution of the 'sovereign, socialist, secular democratic Republic of India' foresaw replacing these community bonds with the state's responsibility for social welfare of the individual citizen. The social objectives as laid out in the 'Directive Principles of State Policy' reflect the state's commitment to promote the welfare of the people and secure for its citizens: 'the right to an adequate means of livelihood'. Inequalities between individuals and groups in income, status, between castes and regions were to be minimised. Labels and ascribed statuses such as 'untouchables' were officially abolished. The Republic committed itself clearly to the universal ideals of justice, liberty, equality and fraternity in its constitutional preamble. But the ideals and Directive principles only set guidelines for policymaking and were not directly enforceable by courts. Additionally, the state's activities in the field of welfare, the rights to work, education, and public assistance were conditional upon the availability of resources, upon 'the limits of its economic capacity and development'.

An exception to these limitations was established for communities of scheduled castes (SC), the former untouchables or Dalits, and scheduled tribes (ST), India's indigenous communities, for 
whom national welfare commissions were set up. The SC and ST were, moreover, assured of a reservation of seats in all legislative bodies from municipal to central level and quotas in public service as well as educational institutions. A key advocate for these affirmative action policies was Bhimrao Ambedkar, leader of the Dalits in the independence movement, president of the Drafting Committee of India's constitution, and later the first Minister of Law. Ambedkar (2008 [1946]) insisted that both would be needed: universal citizenship rights and special provisions for the SC/ST communities, 'rights are nothing unless remedies are provided whereby people can seek to obtain redress when rights are invaded'.

The questions of untouchability and indigenousness thus gained momentum among politicians and moved centre-stage in the social question. In the case of the SG/ST, their earlier social and economic exclusion, as well as continuing discrimination, was successfully framed as an injustice that demanded remedy through state action. In favour of these most disadvantaged groups, a deviation from the principles of universality was made. Although the Constituents Assembly was aware of other reasons for marginalisation, such as gender, religious minority groups or regional origin, despite lengthy debates, no special provisions were made for other marginalised groups at the time (Guha 2007: 111).

\subsection{Welfare through economic modernisation}

How was greater welfare to be achieved for India's population? Corbridge et al. (2005: 54) point out that early conceptions of poverty and measures to tackle it were defined broadly. The state was to become the 'provider, protector and promoter' for the underprivileged millions. On the other hand, key actors of the time attributed the structural causes of poverty and hunger essentially to India's history and economic structures; to the 'legacy of "a traditional society and static economy in the past, petrified to some extent by colonial rule"'. If India was to be remade it needed to 'throw off the shackles of tradition' (Planning Commission 1961, cited in Corbridge et al. 2005: 53).

The subsequent economic reforms essentially shared the British sentiments of 'native' origins of poverty. They aimed at the development of a modern economy built on domestic (heavy) industries. They thereby failed to reach nearly three-quarters of the workforce, who were engaged in agriculture and contributed 60 per cent to India's GDP (Guha 2007: 201).

Consequently, a domestic consumer market did not develop, which impeded further growth of industries (Ghosh 2004). The failure to include wider sections of the workforce in the formal labour market also meant that employmentbased social security provision remained limited in coverage. Such schemes had already been established under British colonial administration, but had hardly gone beyond the 'small segment of the population whose contentment was particularly important for the colonial powers to stabilise their rule' (Loewe 2009). ${ }^{2}$ In the young Republic of India, these policies were extended to public employees in industries and services for whom more extensive social welfare schemes and labour rights were introduced, notably the Employees State Insurance Act of 1948. However, 'social policy which ensured the provision of basic needs to the entire population was never a priority', concludes Ghosh (2004: 293). For the majority, social programmes remained residual in character (de Haan and Sabharwal 2008). A more interventionist social policy agenda, as propagated by Ambedkar, was defeated by Nehru's economic modernisation approach coupled with the belief in economic self-reliance or swadeshi, as advocated by Mohandas Gandhi.

\subsection{The social question unresolved}

India's welfare regime, around the time of its inception, was thus already torn between its universal ideals and inegalitarian traditions, as well as between a reliance on economic modernisation and the perceived limits of its economic capacities. The post-independence welfare regime was marked by a 'high level of social tolerance for high and growing asset inequality, persistent poverty and low levels of human development among vast sections of the population, especially in the rural areas' (Ghosh 2004: 293; also see de Haan and Sabharwal 2008: 71). In the absence of comprehensive welfare policies, the provision of welfare and social security for the majority remained largely in the hands of the traditional institutions of family, village and caste, as well as other religious communities. The Indian state, which propagated state responsibility for the welfare of its constituency, thereby revealed that its redistributive capacity remained limited. 


\section{Reproducing fragmentation: the logic of political society}

From critical junctures, we now turn to the reproduction patterns of India's postindependence welfare trajectory, i.e. the mechanisms that impeded the constitutional call for greater welfare and equality, drawing on Partha Chatterjee's concepts of civil and political society. Chatterjee (2004) highlights the apparent paradox that the ideal of equal citizenship, which is meant to overcome inequality, can actually produce and perpetuate inequalities. He argues that state and society formation in the former colonies are influenced by Western modernity. The encounter with the ideals of democracy and nationhood led to the formation of formally democratic nation-states. But the new democratic political institutions 'cannot be made to work effectively merely by legislating them into existence'; they need to be sustained by a 'network of norms in civil society that prevail independently of the state and that are consistent with its laws' (Chatterjee 2004: 33). Modern political communities rely on (pre-political) foundations: citizens, who 'sustain freedom and equality in the political domain', who deal with the state, based on the principles of 'equality, autonomy, freedom of entry and exit, contract, deliberative procedures of decision-making, recognised rights and duties of members' (Chatterjee 2010 [1997]: 168).

In countries like India, it is only a 'small section of culturally equipped citizens' that forms civil society. Despite the fact that according to the 'formal structure of the state... all of society is civil society; everyone is a citizen... [m] ost of the inhabitants of India are only tenuously and even then ambiguously and contextually, rights bearing citizens in the sense imagined by the constitution' (Chatterjee 2010 [1997]: 38). This large share of the populace forms political society. As opposed to civil society, political society cannot deal with the state on the grounds of universal ideals, because often their livelihood is built on circumvention of the formal law. The violation of health and safety norms in the unorganised sector, or of property rights by slum dwellers, may be perceived as a matter of right to make a living, but their organisations cannot be recognised on a par with civic organisations, which operate in the legal mainstream. The politics of political society are therefore always contextual, temporary and strategic; normatively, they are not bound to universal ideals.
The distinction between political and civil society characterises 'two styles of political engagement that are available to people - the former style is more available to an urbanised elite, the latter to the rest. The availability is fluid and contextual and not fixed by class' (Menon 2010: 11, emphasis in original). The different styles of politics available to civil and political society can be understood as a pattern of reproduction that shaped the Indian welfare regime, because these styles of politics work as reproduction mechanisms as described by Thelen (1999).

\subsection{Incentive structures}

First, the politics of civil and political society can be analysed as incentive structures, to which 'actors adapt their strategies in ways that reflect but also reinforce the "logic" of the system' (Thelen 1999: 392). If the strategic politics of political society are more successful in securing (temporary) gains for its members than civil society politics, and strategic politics therefore become the preferred way of interaction with the state, strategic politics work as incentive structures.

According to Chatterjee (2004), this is the case: despite the transitory and selective nature of strategic politics, political society - more effectively than civil society - does politics for the marginalised. However, this is only acceptable from an outcome-based idea of democratic institutions, which denotes a shift from government of and by the people, to government for the people. Chatterjee argues that government has been turned into technocratic governance, which promises to realise more welfare for more people at smaller cost. The delivery of welfare has become such a successful legitimacy-generating mechanism of the state, it has replaced citizen participation and deliberation (also see Arora 2004: 330; Kumar 2005: 343).

\subsection{Distributional effects}

Thelen (1999: 394) points to a second reproduction mechanism of democratic institutions, which lies in their distributional effects that replicate and magnify particular patterns of power distribution in politics, so that some groups are empowered while others are disarticulated and marginalised. Such a structural advantage has been given to civil society. When civil society in the form of, for example unionised workers, demands health and 
safety regulations at the workplace and access to state-organised social security, they can present these as comprehensive, universal or egalitarian demands. But the benefits from any such changes will only go to a minority of workers as long as 93 per cent of India's workforce is in the unorganised sector and such regulations are effectively not applicable for them. The politics of civil society may seem universal, but in fact they disarticulate the demands of marginalised groups.

Consequently, welfare provisioning 'has not been universal in terms of its actual effects, even when it has been declared as such' (Ghosh 2004: 293).

The claims on government welfare programmes of poor peasants, landless rural workers and daily wage labourers in the cities also needs to be recognised by state agencies. But Chatterjee (2004: 40) stresses that 'those claims could not be regarded as justiciable rights since the state did not have the means to deliver those benefits to the entire population of the country'. In these circumstances, political society has to, and does, find other ways of securing access to welfare, through strategic politics. It does so by making claims for exceptions or preferential treatments. The resulting social policy 'has been directed to specific (and restricted) target groups' (Ghosh 2004: 293; Arora 2004). Consequently, literally several hundred social programmes at central and state level emerged, often with overlapping, though narrowly defined target groups - and with little knowledge about these programmes among potential beneficiaries (de Haan 2008).

The multiplicity of social programmes can be read as evidence for successful political society engagement, which ensured material gains and concessions to particular groupings. In sum, the strategic politics of political society and the only seemingly universal politics of civil society can be seen as a plausible pattern of reproduction, as the sum of incentives for and distributional effects of collective and individual practices, which foster a trajectory of fragmented social and welfare policies in India.

\section{Changing patterns?}

In recent years, this pattern has been confronted with a challenge. Since the general election of 2004 and the formation of the United Progressive Alliance (UPA) government, even although not always on its initiative, ${ }^{3}$ there has been a shift towards social rights-based policies.
Well-known examples are the Right to Information Act (2005), the Mahatma Gandhi National Rural Employment Guarantee Act (MGNREGA) (2005) and the Right to Education Act (2009).

The rights-based paradigm has been heralded as a major change by activists and as a sign that 'India's underprivileged majority is not completely marginalised in this elitist political system' (Drèze 2010: 511). It is taken as an indicator that those who have traditionally not necessarily benefited from a rights discourse, have now successfully employed such.

To Chatterjee, a social rights-based legislation might be civil society politics, and he might question whether parts of the marginalised population can apply civil society measures truly in their favour. He contends that where governmental activities take place 'within the stratified social structures of class, status and privilege' (Chatterjee 2004: 66), the benefits consequently go to those with greater knowledge. Political society, according to him, needs to challenge the governmental technologies, which would otherwise 'continue to proliferate and serve, much as they did in the colonial era, as manipulable instruments of class rule in a global capitalist order' (Chatterjee 2004: 25).

Chatterjee admittedly touches a sensitive issue when he says that civil society politics and seemingly universal policies produce and perpetuate inequalities. His concept does serve as a useful construct to understand the fractioned nature of welfare policies in India. But can the politics of political society really be understood as a potential for 'expansion of democratic political participation' (Chatterjee 2004: 76), as he claims? Procedural democracy, for Chatterjee, is linked in many ways to civil society and its politics, and he does not necessarily expect political society to follow its rules. But he fails to explain whether and how the clan leaders or power-brokers that act as spokespersons for political society will act on behalf of the most marginalised. It is also worth questioning the primarily output-based legitimacy of strategic politics. Whether political society can deliver welfare better in the long run is uncertain, because inequalities are perpetuated in its heterogeneous social constellations. The politics of political society do not offer a sustainable way out, but sustain this welfare regime. 
If rights-based policies are to challenge the mechanisms of political society, this poses a double challenge. The pattern that purportedly universal policies benefit the few who are already privileged needs to be overcome. But even effectively implemented universal policies with a better performance would only question and potentially delegitimise the output-based argument. To turn around the unfavourable reproduction mechanisms of civil and political society politics, that have sustained the fragmented welfare regime for too long, more drastic changes in the working of Indian democracy are needed. This task cannot be achieved by social protection policies alone. The community-based nature of the MGNREGA, with its emphasis on local decision-making, social audit and transparency guarantees might point to the right direction. Yet, several studies highlight that much remains to be done concerning both equal inputs of citizens and more equitable outputs (see Drèze 2010; Ehmke 2011).

\section{Notes}

* I want to thank Stephen Devereux, Gabriele Koehler, Daniel Leisegang, Rachel SabatesWheeler, Lisbeth Zimmermann and participants at the conference 'Social Protection for Social Justice' for comments on earlier versions of this article. All remaining errors are mine.

1 Gough and his co-authors identify three 'meta-regime' types: proto-welfare state regimes, informal security regimes and insecurity regimes, which differ from the OECD welfare states in four fields (Gough 2004: 26). First, state institutions are less autonomous and democratic practice might be absent. Market capitalism is not necessarily the dominant form of economic organisation. Second, in the South, the trio of state, market and family has to be extended to include community, which is a fourth major source of welfare production, and each of these four also has an international dimension. Third, welfare outcomes tend to be generally lower

\section{Conclusion}

In terms of social policymaking, this article suggests that it is a narrow path between universal policies that treat unequals as equal, and giving in to the plurality of particular demands. In the Indian context, an adverse combination of both produces socially unjust outcomes. The heterogeneity of political society and its politics have been an obstacle for the formation of a common horizon of solidarity. Together with the only ostensibly universal politics of civil society, they formed a reproduction pattern which did not challenge the historically high acceptance of inequalities, and these continue to form an impediment to redistributive policies. This pattern obstructed the realisation of the constitutional commitment to greater welfare. If this pattern was to be overcome by a rights- and citizen-based approach, it would offer opportunities for more substantial institutional change of India's social policy in the future. It could be a turning point in India's history of fragmented and overlapping organisation of welfare.

than in OECD countries for at least the biggest part of the population. Fourth, political mobilisation of elites and other societal groups, as well as stratification, differ from the Global North.

2 The English, who had been among the first nations to install a 'poor relief' at home, reacted to urban poverty in India with containment, and the problem of the rural poor was perceived as a result of their backwardness, untouchability and of 'Indianness' itself (Corbridge et al. 2005: 52). Although British rule had partially eroded the old economic order and decreased the ability of the population to secure self-sufficiency, the cause of poverty was not attributed to the new (colonial) but to the traditional economic regime.

3 Another active role was played by India's Supreme Court, its proactive judiciary has been vital for the extension of social rights, for example the right to a mid-day meal at school for pupils (Chandhoke 2007). 


\section{References}

Ambedkar, B. (2008 [1946]) 'On the Aims and Objectives of the Constitution' (9 December 1946), in S. Thorat and N. Kumar (eds), B.R. Ambedkar: Perspectives on Social Exclusion and Inclusive Policies, New Delhi: Oxford University Press

Arora, D. (2004) 'Welfare Discourse in India', in M.M. Sankhdher and S. Jain (eds), Social Security, Welfare and Polity, New Delhi: Deep \& Deep

Chandhoke, N. (2007) 'Democracy and Well-Being in India', in Y. Bangura (ed.), Democracy and Social Policy, Basingstoke: Palgrave Macmillan

Chatterjee, P. (2010 [1997]) 'Beyond the Nation? Or Within?', in N. Menon (ed.), Empire and Nation: Partha Chatterjee: Essential Writings 1985-2005, Ranikhet: Permanent Black

Chatterjee, P. (2004) 'The Politics of the Governed: Reflections on Popular Politics in Most of the World', The Leonard Hastings Schoff Memorial Lectures, New York: Columbia University Press Corbridge, S.; Williams, G.; Srivastava, M. and Véron, R. (2005) Seeing the State: Governance and Governmentality in India, Cambridge: Cambridge University Press

de Haan, A. (2008) 'Inequalities within India's Poorest Regions: Why do the same Institutions Work Differently in Different Places?', in A.A. Dani and A. de Haan (eds), Inclusive States: Social Policy and Structural Inequalities, Washington DC: World Bank de Haan, A. and Sabharwal, G. (2008) 'South and East Asian Social Policy Experience: Politics and Institutions in the Extension of Social Security', Indian Journal of Human Development 2: $63-78$

Drèze, J. (2010) 'Employment Guarantee and the Right to Work', in N.G. Jayal and P.B. Mehta (eds), The Oxford Companion to Politics in India, New Delhi: Oxford University Press

Ehmke, E. (2011) 'Indien - Arbeit für Alle? Das größte Beschäftigungsprogramm der Welt', Blätter für Deutsche und Internationale Politik 8: 81-8

Ghosh, J. (2004) 'Social Policy in Indian Development', in T. Mkandawire (ed.), Social Policy in a Development Context, Basingstoke: Palgrave Macmillan
Gough, I. (2008) 'European Welfare States: Explanations and Lessons for Developing Countries', in A.A. Dani and A. de Haan (eds), Inclusive States: Social Policy and Structural Inequalities, Washington DC: World Bank

Gough, I. (2004) 'Welfare Regimes in Development Contexts: A Global and Regional Analysis', in I. Gough, G. Wood, A. Barrientos, P. Bevan, P. Davis and G. Room (eds), Insecurity and Welfare Regimes in Asia, Africa and Latin America: Social Policy in Development Contexts, Cambridge: Cambridge University Press

Guha, R. (2007) India after Gandhi: The History of the World's Largest Democracy, London: Macmillan

Haggard, S. and Kaufman, R.R. (2008) Development, Democracy and Welfare States: Latin America, East Asia and Eastern Europe, Princeton: Princeton University Press

Jürgenmeyer, C. and Rösel, J. (2009) 'Hierachie und Differenz - Die Indische Kastengesellschaft', Der Bürger im Staat 59: 206-14

Kumar, A. (2005) 'The Welfare State System in India', in B. Vivekanandan and N. Kurian (eds), Welfare States and the Future, Basingstoke: Palgrave Macmillan

Loewe, M. (2009) 'Right to Social Security in Development: Facilitating National Conditions: What Action is Needed?', paper prepared for the conference Right to Social Security in Development, Berlin: Friedrich Ebert Foundation

Menon, N. (2010) 'Introduction', in N. Menon (ed.), Empire and Nation: Partha Chatterjee: Essential Writings 1985-2005, Ranikhet: Permanent Black

Muzumdar, A.M. (1964) Social Welfare in India: Mahatma Gandhi's Contribution, Bombay: Asia Publishing House

Rudra, N. (2007) 'Welfare States in Developing Countries: Unique or Universal?', Journal of Politics 69: 378-96

Thelen, K. (1999) 'Historical Institutionalism in Comparative Politics', Annual Review of Political Science 2: 369-404 